\title{
Use of a nylon-bag technique for pig feed digestibility studies
}

\author{
BY HADDEN GRAHAM, PER AMAN, ROSEMARY K. NEWMAN* \\ AND C. WALT NEWMAN* \\ Department of Animal Nutrition and Management, Swedish University of \\ Agricultural Sciences, S-75007 Uppsala, Sweden
}

(Received 31 July 1984 - Accepted 4 July 1985)

\begin{abstract}
1. The use of a nylon-bag technique for pig feed digestibility determination was studied. Bags, measuring $25 \times 40 \mathrm{~mm}$ and containing feed samples, were introduced into the pig gastrointestinal tract through a duodenal cannula, and recovered in the faeces between 23 and $69 \mathrm{~h}$ later. The disappearance of organic matter and crude protein (nitrogen $\times 6.25$ ) from the bags was compared with in vivo apparent digestibility, determined by conventional faecal-collection methods, and neutral-detergent-fibre content for eleven feeds. The residues left in the bags after passage through the intestine from whole-crop-pea (Pisum sativum) and barley-grain samples were analysed for starch, non-starch polysaccharide residues, Klason lignin, crude protein and ash.

2. Dry matter disappearance of barley or whole-crop peas was not influenced by increasing bag pore size from 10 to $36 \mu \mathrm{m}$ ar sample weight from 250 to $1000 \mathrm{mg}$. Pepsin (EC 3.4.2.1) pretreatment had no effect on the degradation in the bags of the feeds investigated.

3. Organic matter and crude protein disappearance from the bags exceeded in vivo apparent digestibility by up to 0.10 and 0.42 units respectively. In vivo apparent organic matter digestibility could be predicted $(P<0.001)$ by the organic matter disappearance from the bags and the neutral-detergent-fibre content of the feed, while in vivo apparent crude protein digestibility was highly correlated $(P<0.001)$ to all these indices but poorly to crude
\end{abstract} protein disappearance from the bags.

4. Klason lignin was the least degraded component measured in the whole-crop-pea and barley residues from the bags, while starch was completely digested. Of the non-starch polysaccharide residues, xylose was the most resistant to degradation in both samples whereas other sugars varied in susceptibility to solubilization between samples.

5. Results are discussed in relation to the potential uses of the nylon-bag technique described in the present paper for studies in simple-stomached animals.

The determination of digestibility by conventional methods requires a large quantity of feed, a number of animals, and considerable expenditure on equipment and manpower. Analysis of faecal residues provides little information on the degradation of components of individual feeds due to the number of feed constituents often necessary to provide a nutritionallyadequate diet and to contamination by endogenous and bacterial material during digestion. In ruminant studies several methods, including degradation of small samples of feed in bags placed in the rumen, are widely and routinely used for studying the pattern and extent of feed digestion. However, no equivalent method is currently accepted for investigating digestion in simple-stomached animals. Recent work has shown that the digestion of feed samples, contained in nylon bags and passed through the gastrointestinal tract of pigs, could be used in the rapid determination of feed quality (Petry \& Handlos, 1978; Sauer et al. 1983). Prolonged retention of the bags in the stomach can be overcome by introduction through a duodenal cannula (Sauer et al. 1983). However, discrepancies between these two studies in methods used and results obtained, particularly with regard to bag pore size and extent of crude protein (nitrogen $\times 6.25$ ) disappearance from the bags relative to in vivo apparent digestibility, require further investigation. The present experiments were also designed to provide information on a nylon-bag method and include chemical analysis of degraded residues from the bags. The suitability of a nylon-bag technique for predicting

\footnotetext{
* Visiting Fellows from Montana State University,Bozeman, MT 59717, U.S.A.
} 
Table 1. The neutral-detergent fibre $(N D F)$ content, crude protein $(C P$, nitrogen $\times 6 \cdot 25)$ content and neutral-detergent solubility of crude protein (NDSCP) of the feeds examined, and the number and weight of pigs used in in vivo trials

\begin{tabular}{|c|c|c|c|c|c|}
\hline \multirow[b]{2}{*}{ Feed } & \multicolumn{3}{|c|}{ Feed composition } & \multicolumn{2}{|c|}{ Pigs } \\
\hline & $\begin{array}{l}\mathrm{NDF} \\
(\mathrm{mg} / \mathrm{g})\end{array}$ & $\underset{(\mathrm{mg} / \mathrm{g})}{\mathrm{CP}}$ & NDSCP & No. & $\begin{array}{l}\text { Live wt } \\
(\mathrm{kg})\end{array}$ \\
\hline Wheat & 115 & 131 & 0.888 & 9 & $15-30$ \\
\hline Triticale & 130 & 116 & 0.849 & 9 & $15-30$ \\
\hline Rye & 139 & 98 & 0.802 & 9 & $15-30$ \\
\hline Barley & 164 & 127 & 0.864 & 18 & $15-30$ \\
\hline Distillers' grains $1^{*}$ & 236 & 247 & 0.912 & 8 & $15-30$ \\
\hline Distillers' grains $2 \dagger$ & 246 & 293 & 0.857 & 6 & $40-70$ \\
\hline $\begin{array}{l}\text { Rapeseed meal } \\
\text { (Brassica napus) }\end{array}$ & 296 & 440 & 0.908 & 6 & $40-70$ \\
\hline $\begin{array}{l}\text { Whole-crop peas } \\
\text { (Pisum sativum) } 1 \$\end{array}$ & 381 & 203 & $0 \cdot 930$ & 7 & $30-70$ \\
\hline Whole-crop peas $2 \ddagger$ & 352 & 152 & 0.932 & 8 & $30-70$ \\
\hline Clover (Trifolium repens) & 337 & 214 & 0.896 & 8 & $25-65$ \\
\hline Grass & 599 & 145 & 0.619 & 8 & $25-65$ \\
\hline
\end{tabular}

* Wheat-based and $\dagger$ dehulled barley-based grains.

$\ddagger 1,2$, Early and late harvests respectively.

in vivo apparent digestibility of organic matter (AOMD) and, indirectly, of crude protein is reported.

\section{METHODS}

Digestibility studies

Feeds examined were barley, wheat, rye and triticale grains, wheat-based (sample 1) and dehulled barley-based (sample 2) distillers' grains, extracted rapeseed (Brassica napus) meal, early (sample 1) and late (sample 2) harvested whole-crop peas (Pisum sativum), clover (Trifolium repens) and grass (see Table 1).

Three 8-month-old pigs weighing between 80 and $120 \mathrm{~kg}$, and fitted with steel ' $T$ '-shaped duodenal cannulas (Björnhag \& Jonsson, 1984), were used for the determination of digestibility in bags. The pigs were given daily $3 \mathrm{~kg}$ of a commercial pig diet $((\mathrm{g} / \mathrm{kg}): 270$ barley, 270 oats, 270 wheat, 50 peas, 50 soya-bean meal, 50 fish meal, 40 vitamin and mineral supplement, 175 crude protein) in two equal meals at 08.00 and 16.00 hours, and had access to straw bedding. When bags were being inserted, each meal was divided into three portions with a 30-min interval between feeding each portion. Up to six bags, containing samples, were introduced through the cannula during feeding of both the second and third portions of morning and afternoon feeds. Bags were retrieved immediately after defaecation, extensively washed in cold water to remove contaminating faecal material, frozen and freeze-dried. Bags, measuring $40 \times 25 \mathrm{~mm}$, were machine sewn. All feed samples were milled to pass a $1 \mathrm{~mm}$ screen before determinations of digestibility using bags.

In vivo digestibilities were determined using at least six growing-finishing pigs $(15-70 \mathrm{~kg})$ per feed (see Table 1) and details have been published elsewhere (Håkansson \& Malmlöf, 1984; C. W. Newman, S. Lund and M. Rundgren, personal communication). After a $7 \mathrm{~d}$ adaptation period the pigs were individually placed in conventional digestion crates and faeces collected twice daily ( 08.00 and 16.00 hours) for $4 \mathrm{~d}$. Faeces were pooled for each 
Table 2. The in vivo digestibility, and the disappearance from nylon bags passed through pigs, of organic matter and crude protein (nitrogen $\times 6.25$ ) for eleven pig feeds (Mean values with their standard errors; no. of replicates given in parentheses for the in vivo determinations)

\begin{tabular}{|c|c|c|c|c|c|c|c|c|}
\hline \multirow[b]{3}{*}{ Feed } & \multicolumn{4}{|c|}{ Organic matter } & \multicolumn{4}{|c|}{ Crude protein } \\
\hline & \multicolumn{2}{|c|}{ in vivo } & \multicolumn{2}{|c|}{ From bags* } & \multicolumn{2}{|c|}{ in vivo } & \multicolumn{2}{|c|}{ From bags* } \\
\hline & Mean & $\mathrm{SE}$ & Mean & $\mathrm{SE}$ & Mean & $\mathrm{SE}$ & Mean & $\mathrm{SE}$ \\
\hline Wheat & 0.885 & $0.005(9)$ & 0.935 & 0.005 & 0.804 & $0.016(9)$ & 0.965 & 0.006 \\
\hline Triticale & 0.885 & $0.005(9)$ & 0.928 & 0.005 & 0.775 & $0.016(9)$ & 0.949 & 0.008 \\
\hline Rye & 0.880 & $0.005(9)$ & 0.915 & 0.005 & 0.713 & $0.016(9)$ & 0.937 & 0.007 \\
\hline Barley & 0.831 & $0.003(18)$ & 0.889 & 0.007 & $0 \cdot 742$ & $0.011(18)$ & 0.955 & 0.008 \\
\hline Distillers' grains 1 & 0.742 & $0.012(8)$ & 0.809 & 0.007 & 0.755 & $0.012(8)$ & 0.936 & 0.009 \\
\hline Distillers' grains 2 & 0.700 & $0.012(6)$ & 0.786 & 0.015 & 0.673 & $0.016(6)$ & 0.956 & 0.019 \\
\hline $\begin{array}{l}\text { Rapeseed meal } \\
\text { (Brassica napus) }\end{array}$ & 0.671 & $0.030(6)$ & 0.754 & 0.012 & 0.763 & $0 \cdot 035(6)$ & 0.925 & 0.009 \\
\hline $\begin{array}{l}\text { Whole-crop peas } \\
\text { (Pisum sativum) } 1\end{array}$ & 0.646 & $0.039(7)$ & 0.677 & 0.008 & 0.627 & $0.091(7)$ & 0.942 & 0.011 \\
\hline Whole-crop peas 2 & 0.594 & $0.038(8)$ & 0.692 & 0.020 & 0.522 & $0.075(8)$ & 0.927 & 0.027 \\
\hline $\begin{array}{l}\text { Clover } \\
\text { (Trifolium repens) }\end{array}$ & 0.614 & $0.071(8)$ & 0.686 & 0.021 & 0.574 & $0.088(8)$ & 0.936 & 0.030 \\
\hline Grass & 0.554 & $0.070(8)$ & 0.562 & 0.023 & 0.471 & $0 \cdot 106(8)$ & 0.888 & 0.020 \\
\hline
\end{tabular}

* Six replicates.

pig, weighed and analysed for organic matter and crude protein. The digestibilities of barley, wheat, rye and triticale were determined by feeding with a vitamin and mineral supplement $(40 \mathrm{~g} / \mathrm{kg}$ fresh weight) whereas those of the other feeds were calculated by difference following inclusion $(30 \mathrm{~g} / \mathrm{kg}$ fresh weight) with a standardized diet.

\section{Analytical methods}

Dry matter, ash and crude protein were determined by standard methods (Association of Official Analytical Chemists, 1975). Starch was determined enzymically (Åman \& Hesselman, 1984), uronic acids by decarboxylation (Theander \& Aman, 1979) and neutral-detergent fibre as described by Robertson \& Van Soest (1981). Klason lignin was measured gravimetrically as the sulphuric-acid-insoluble fraction, and non-starch neutral sugars were determined by gas-liquid chromatography as alditol acetates following acid-hydrolysis of the starch-free residue (Theander \& Åman, 1979).

\section{Experimental procedure}

In Expt 1, 250, 500 or $1000 \mathrm{mg}$ barley or whole-crop-pea samples were digested in triplicate in precision-woven nylon-cloth bags (ZBF AG, CH-8803 Rüschlikon) with pore sizes of 10,20 or $36 \mu \mathrm{m}$, and dry matter disappearance (DMD) determined. In Expt 2, 20- $\mu \mathrm{m}$ pore-size bags containing $500 \mathrm{mg}$ whole-crop-pea, clover and grass samples or $1000 \mathrm{mg}$ of the grain and rapeseed-meal samples were employed. Triplicate samples were either introduced into the duodenum directly, or following incubation with pepsin (EC 3.4.2.1) ( $3 \mathrm{~h}, 37^{\circ}, 460$ units $/ \mathrm{ml}$ in $0.01 \mathrm{M}$-hydrochloric acid). All residues were dried, weighed and analysed for organic matter and N. In Expt 3, barley (1000 mg, twenty replicates) or whole-crop peas $2(500 \mathrm{mg}$, fourteen replicates) were digested in $20-\mu \mathrm{m}$ pore bags. Residues were dried and pooled for analysis. 
Table 3. First-order regression analysis between in vivo apparent digestibility, and disappearance from nylon bags of organic matter $(O M)$ and crude protein (nitrogen $\times 6 \cdot 25 ; C P$ ), neutral-detergent solubility of crude protein (NDSCP) and neutral-detergent fibre (NDF) content, for eleven pig feeds

\begin{tabular}{llccc}
\hline $\begin{array}{l}\text { Independent } \\
\text { variable }\end{array}$ & $\begin{array}{l}\text { Dependent } \\
\text { variable }\end{array}$ & Intercept & $\begin{array}{c}\text { Coefficient } \\
\text { of regression }\end{array}$ & $\begin{array}{c}\text { Coefficient of } \\
\text { determination }\end{array}$ \\
\hline in vivo OM & Bags OM & 0.08 & 0.97 & $0.95 * * *$ \\
& NDF & 1.00 & -1.01 & $0.82^{* * *}$ \\
in vivo CP & Bags CP & 0.85 & 0.13 & $0.50^{*}$ \\
& NDSCP & 0.64 & 0.32 & $0.16 \mathrm{NS}$ \\
& in vivo OM & 0.09 & 0.94 & $0.70^{* * *}$ \\
& Bags OM & 0.13 & 0.97 & $0.76^{* * *}$ \\
& NDF & 1.04 & -1.14 & $0.78^{* * *}$ \\
\hline
\end{tabular}

NS, not significant.

${ }^{*} P<0.05,{ }^{* * *} P<0.001$.

In all experiments, samples of each feed were replicated between pigs and introduction (i.e. morning or afternoon) time.

\section{RESULTS \\ Expt 1}

The mean DMD from the bags of barley and whole-crop peas was 0.881 (SE 0.009 , range $0.873-0.888$ ) and 0.703 (SE 0.016 , range $0.675-0.730$ ), and was not influenced by changing bag pore-size between 10 and $36 \mu \mathrm{m}$ or by increasing sample weight from 250 to $1000 \mathrm{mg}$.

\section{Expt 2}

Pepsin pretreatment did not influence digestion in bags, therefore values were pooled. Organic matter disappearance (OMD) from bags for all feeds exceeded in vivo AOMD by $0.01-0.10$ units while crude protein disappearance from bags was greater than 0.88 for all feeds and exceeded that of in vivo apparent digestion by 0.14-0.41 units (Table 2). Linear regression of these results demonstrated that in vivo AOMD could be predicted $(P<0.001)$ from both OMD from bags and neutral-detergent-fibre content (Table 3), although the coefficient of determination was higher for the bag method. The latter two indices were also closely correlated $\left(R^{2} 0.95\right)$. Crude protein in vivo apparent digestibility was poorly related with disappearance from bags and neutral-detergent solubility of $N$ (Table 3 ) but was correlated $(P<0.001)$ with in vivo AOMD, OMD from bags and neutral-detergent-fibre content.

\section{Expt 3}

The DMD from bags of the barley and whole-crop-pea feeds were 0.879 (SE 0.010 ) and 0.704 (SE 0.023) respectively. Starch was almost completely degraded, and non-starch polysaccharides and Klason lignin were the major components of both residues (Table 4). Klason lignin was the least-degraded constituent with a more than six-fold increase in relative content during digestion of the barley sample. Glucose and xylose were the predominant polysaccharide constituents in the residues and xylose was the least-degradable polysaccharide residue in both samples. The other neutral-sugar residues varied in susceptibility to solubilization between the two feeds, while uronic acids accumulated in the 
Table 4. Composition ( $\mathrm{mg} / \mathrm{g}$ ) of undigested feed and residues of barley and whole-crop peas (Pisum sativum) from nylon bags passed through pigs, and the disappearance from the bags of each component

\begin{tabular}{|c|c|c|c|c|c|c|}
\hline \multirow[b]{2}{*}{ Component } & \multicolumn{3}{|c|}{ Barley } & \multicolumn{3}{|c|}{ Whole-crop peas } \\
\hline & $\begin{array}{l}\text { Undigested } \\
\text { feed }\end{array}$ & $\begin{array}{c}\text { Residue } \\
\text { from bags }\end{array}$ & Disappearance & $\begin{array}{l}\text { Undigested } \\
\text { feed }\end{array}$ & $\begin{array}{c}\text { Residue } \\
\text { from bags }\end{array}$ & Disappearance \\
\hline Ash & 26 & 76 & 0.662 & 59 & 45 & 0.803 \\
\hline Crude protein & 127 & 45 & 0.957 & 152 & 33 & 0.936 \\
\hline Starch & 575 & $<5$ & $>0.999$ & 162 & $<5$ & $>0.991$ \\
\hline Klason lignin & 30 & 195 & 0.220 & 81 & 169 & 0.387 \\
\hline Total NSP: & 155 & 551 & 0.573 & 352 & 610 & 0.491 \\
\hline Rhamnose & Trace & Trace & -- & 4 & 3 & 0.780 \\
\hline Arabinose & 20 & 71 & 0.574 & 17 & 6 & 0.896 \\
\hline Xylose & 43 & 204 & 0.431 & 57 & 150 & 0.226 \\
\hline Mannose & 3 & 6 & 0.760 & 7 & 10 & 0.580 \\
\hline Galactose & 3 & 8 & 0.680 & 14 & 9 & 0.811 \\
\hline Glucose & 79 & 230 & 0.651 & 182 & 376 & 0.393 \\
\hline Uronic acids & 7 & 32 & 0.451 & 71 & 56 & 0.768 \\
\hline
\end{tabular}

NSP, non-starch polysaccharides.

Table 5. The disappearance of dry matter of barley or whole-crop peas (Pisum sativum) from nylon bags passed through three pigs

(Mean values with their standard errors; no. of replicates in parentheses)

\begin{tabular}{|c|c|c|c|c|c|c|}
\hline & \multicolumn{2}{|c|}{ Pig 1} & \multicolumn{2}{|c|}{ Pig 2} & \multicolumn{2}{|c|}{ Pig 3} \\
\hline & Mean & SE & Mean & SE & Mean & SE \\
\hline Barley & 0.884 & $0.007(8)$ & 0.879 & $0.010(10)$ & 0.879 & $0.006(10)$ \\
\hline Whole-crop peas & 0.697 & $0.019(8)$ & 0.702 & $0.021(8)$ & 0.695 & $0.018(8)$ \\
\hline
\end{tabular}

barley and diminished in the whole-crop peas during digestion. Protein loss was high in both samples, and about $60 \%$ of the residual $\mathrm{N}$ and $14 \%$ of the dry matter were neutraldetergent soluble.

\section{General}

The results obtained from the nylon-bag method were more reproducible than those from the in vivo study and the average standard errors of means for the dry matter and crude protein losses from the bags for the eleven feeds examined (six replicates for each) were 0.012 and 0.015 respectively (Table 2 ). The variability tended to increase as potential degradability decreased, but little between-pig variation was apparent in the present study (Table 5).

The mean gastrointestinal retention time of the bags placed in the tract at afternoon feeding (43.7 h, SE 11.9, seventy-eight samples) exceeded that of those introduced in the morning (37.0 h, SE 10.1, seventy-six samples). Bags were retained for between 23 and $69 \mathrm{~h}$ and, while $66 \%$ of the bags introduced in the morning were recovered the following day, only $20 \%$ of the samples administered in the afternoon were retrieved the next evening. Samples were not recovered in the order that they were introduced into the pig, and the 
retention times of bags placed simultaneously in the duodenum differed by up tol $8 \mathrm{~h}$. Retention time did not influence the extent of barley degradation but DMD from the bags of the whole-crop-pea sample 2 increased by 0.002 units $/ \mathrm{h}$ with retention time $(P<0.001$; DMD at zero time of 0.599 ).

\section{DISCUSSION}

Choice of bag pore size for digestibility studies is essentially a compromise between minimizing feed particle exchange and maximizing liquid and bacterial flow between the bag contents and its environment. A pore size of $20 \mu \mathrm{m}$ permits bacterial exchange (Lindberg et al. 1984) and did not hinder degradation of barley or whole-crop peas in the present study. That increasing bag pore size from 10 to $36 \mu \mathrm{m}$ did not influence DMD from either sample examined would suggest that the feed particles lost through the larger pores consisted of potentially-degradable material. However, particle loss from the bags, which depends on pore size and feed-particle size distribution, could be a source of error in this method.

$\mathrm{Up}$ to $1 \mathrm{~g}$ barley or whole-crop peas did not impede digestion. This sample size relative to bag surface area greatly exceeds that recommended for rumen studies (see Lindberg, 1983) and this difference may be due to the relative physiology of the respective digestive organs or to the rapid reduction of effective sample size following the solubilization of readilydegradable components from the samples in the pig duodenum. That pepsin pretreatment did not influence $\mathbf{N}$ disappearance from the bags is not surprising considering the capacity of the postduodenal intestinal tract, and in particular the caecum-colon, to degrade protein (Just et al. 1981; Zebrowska, 1982).

The extensive degradation in bags of the non-starch polysaccharides and lignin in the feeds investigated (Table 4) demonstrates the importance of microbial activity in the gastrointestinal tract. The pattern of solubilization of non-starch polysaccharide residues in the whole-crop peas from the bags was similar to that observed in in vitro ruminant studies (P. Åman, 1984; unpublished results) and in vivo pig studies (Graham et al.1985). The accumulation of uronic acid and arabinose residues during degradation of the barley indicates that these sugars are primarily present as relatively indigestible xylans (Bacic \& Stone, 1981; Van Soest, 1982). In the pea crop, however, these sugar residues are also found in degradable pectins (Van Soest, 1982). The relatively high solubilization of non-starch glucose in the barley was probably due to the presence of mixed-linked $\beta$-glucans which are susceptible to microbial degradation (Bacic \& Stone, 1981). As previously shown for faecal digestibilities of a cereal-based diet and whole-crop peas in pigs (Graham et al.1985), xylans were the least-degradable polysaccharide in both feeds investigated. The increase in DMD from the bags of the whole-crop peas, but not the barley, with retention time in the pigs is probably indicative of the more resistant lignocelluloses found in the hulls of the latter sample.

The difference between organic matter degradation in the bags and in vivo may be partly due to particle losses from the bags, the smaller feed-particle size in the bag method relative to in vivo studies, and the presence of endogenous and microbial material in faeces. The use of mature pigs, with a more-developed microflora and large intestine (see Mason, 1980), in the bag studies probably also contributed to this difference. However, the use of mature pigs greatly extends the experimental life of surgically-altered animals and should increase reproducibility both within and between experiments. Although Petry \& Handlos (1978) could detect no influence of pig diet on feed degradation in bags, diet can influence microbial activity in the caecum-colon of pigs (Ehle et al. 1982). Further investigations into the effect of dietary composition, particularly of degradable fibres or heat-damaged proteins, on the extent and pattern of degradation in bags are necessary. 
Petry \& Handlos (1978), using bags of $5-\mu \mathrm{m}$ pore size, found that organic matter and protein digestibilities were about $3 \%$ lower and up to $17 \%$ higher respectively than in vivo values, whereas Sauer et al. (1983), with bags of $50-\mu \mathrm{m}$ pore size, reported that protein degradabilities determined by both methods were similar. Both investigations were carried out with growing pigs $(30-80 \mathrm{~kg}$ ), which could partly account for the lower degradability of the feeds in bags in these studies compared with the present experiment. However, as the bags were not washed on retrieval in the two investigations discussed, the major cause of this discrepancy is probably the contamination of residues in the bags by faecal material. This contamination, which will be greater when larger bag pore sizes are employed, will particularly influence the apparent $\mathrm{N}$ content of the residues and result in a large variation in degradability measured in bags between experiments, depending on the method used to isolate the bags from the faeces. The high neutral-detergent solubility of the $\mathrm{N}$ in the residues from bags in the present study suggested some microbial contamination (see Robertson \& Van Soest, 1981) despite careful washing, and this was confirmed by microscopic examination.

The high protein-disappearance values from bags for all feeds could have resulted from the loss of feed particles and the solubilization of nitrogenous compounds which are not digested in vivo. However, as previously discussed, most particles lost would seem to be potentially degradable and, assuming uniform content of $\mathrm{N}$ in the undegraded particles, such losses would result in an equal disappearance of organic matter. Also, water-soluble nitrogenous compounds found in pig faeces account for only about $25 \%$ of faecal $\mathrm{N}$ irrespective of the fibre content of the diet, and consist mainly of partially-degraded endogenous secretions (Mason et al. 1982). The low $\mathrm{N}$ content of the residues from the bags and of the neutral-detergent fibre of the original feeds in this investigation concur with earlier observations that low in vivo apparent crude-protein digestibilities of many high-fibre feeds are not due to the presence of non-degradable fibre-bound N (Ehle et al.1982; Mason et al. 1982). Assuming that $13 \%$ of the $\mathrm{N}$ in pig faeces is undigested dietary $\mathrm{N}$ (Mason et al. 1982), it can be estimated that the disappearance of crude protein from the bags in the present study was an underestimation of in vivo actual digestibility of $\mathrm{N}$ in all feeds, possibly because of microbial contamination of the degraded residues in the bags. The difference between $\mathrm{N}$ degradation measured in vivo and in bags would be narrowed by up to 0.05 units by recalculating in vivo values as 'true' protein digestibility by traditional methods (see Eggum, 1973). However, Mason (1980) has shown that estimates of 'true' protein digestibility by the conventional approach can differ by up to $0 \cdot 1$ units depending on the $\mathrm{N}$ content of the diet and on the value accepted for metabolic faecal $\mathrm{N}$ excretion, and will be an underestimate of the actual digestibility of highly digestible proteins contained in natural feeds.

The nylon-bag technique described may be used to predict the in vivo apparent digestibility of pig feeds and would be particularly useful for a rapid comparison of a large number of similar samples. The inclusion of standardized feeds, preferably similar in composition and physical characteristics to the test samples, and the use of mature pigs would increase continuity between experiments. Providing that several cannulated pigs with similar feed retention times are available, a large number of samples may be investigated at one time; for example, in the present experiment with three pigs, up to twelve feeds, each with six replicates, could be examined daily. Analysis of partially degraded residues from the bags could provide valuable information on the feed components resistant to digestion and on the influence of treatments on feed degradation in simple-stomached animals. 
The authors wish to acknowledge the contribution of S. Lund and Dr J. Håkansson who provided in vivo values for the pea, clover and grass feeds; $\mathbf{M}$. Rundgren and Professor S. Thomke who provided in vivo values for the distillers' grain and rapeseed meal; and E. Jonsson and Dr G Björnhag who cannulated the pigs. This work was in part financially supported by The Swedish Council for Forestry and Agricultural Research.

\section{REFERENCES}

Åman, P. \& Hesselman, K. (1984). Swedish Journal of Agricultural Research 14, 135-139.

Association of Official Analytical Chemists (1975). Official Methods of Analysis,12th ed. Washington, DC: Association of Official Analytical Chemists.

Bacic, A. \& Stone, B. A. (1981). Australian Journal of Plant Physiology 8, 475-495.

Björnhag, G.\& Jonsson, E. (1984). Livestock Production Science 11,179-184.

Eggum, B. O.(1973). Beretning fra Forsogslaboratoriet no. 406. Copenhagen: National Institute of Animal Science.

Ehle, F. R., Jeraci, J. L., Robertson, J. B. \& Van Soest, P. J. (1982). Journal of Animal Science 55, $1071-1081$.

Graham, H., Hesselman, K. \& Áman, P. (1985). In Digestive Physiology in the Pig, pp. 195-198. [A. Just, H. Jørgensen and J. A. Fernandez, editors]. Copenhagen: National Institute of Animal Science.

Håkansson, J. \& Malmlöf, K.(1984). Swedish Journal of Agricultural Research 14, 45-51.

Just, A., Jørgensen, H. Fernańdez, J. A. (1981). British Journal of Nutrition 46, 209-219.

Lindberg, J. E. (1983). Department of Animal Nutrition, Report no. 59. Uppsala: Swedish University of Agricultural Sciences.

Lindberg, J. E., Kaspersson, A. \& Ciszuk, P. (1984). Journal of Agricultural Science, Cambridge 102, $501-504$.

Mason, V. C. (1980). In Current Concepts of Digestion and Absorption in Pigs, no 3, pp. 112-129 [A. G. Low and I. G. Partridge, editors]. Reading: National Institute for Research in Dairying.

Mason, V. C.,Kragelund, Z. \& Eggum, B. O. (1982). Zeitschrift für Tierphysiologie, Tierernährung und Futtermittelkunde 48, 241-252.

Petry, H. \& Handlos, B. M. (1978). Archiv für Tierernährung 28, 531-543.

Robertson, J. B. \& Van Soest, P. J. (1981). In The Analysis of Dietary Fiber in Foods, pp. 123-158. [W. P. T. James and O. Theander, editors]. New York: Marcel Dekker.

Sauer, W. C., Jørgensen, H. \& Berzins, R. (1983). Canadian Journal of Animal Science 63, $233-237$.

Theander, O. \& Âman, P. (1979). Swedish Journal of Agricultural Research 9, 97-106.

Van Soest, P. J. (1982). Nutritional Ecology of the Ruminant, Oregon:O \& B Books.

Zebrowska, T.(1982). In Digestive Physiology in the Pig, pp. 225-236. [J. P.Laplace, T. Corring and A. Rerat, editors]. Paris: Institut National de la Recherche Agronomique. 